\title{
MENENTUKAN PENGUKURAN KECEPATAN SIMULASI KERETA API BERBASIS MICROKONTROLER (ARDUINO) DENGAN MENGGUNAKAN BILANGAN KOMPLEKS
}

\author{
Supriyatna $^{1)}$, Imas Ratna Ermawati' ${ }^{2}$, Reza Annisa Salsabilla ${ }^{3)}$ \\ 1,2, 3) Fkip, Universitas Muhammadiyah Prof. DR. HAMKA \\ Jl. Tanah Merdeka, Pasar Rebo, Jakarta 13830 \\ Email: Supriyatna1379@gmail.com ${ }^{1}$, \\ Imas_re@uhamka.ac.id ${ }^{2}, \underline{\text { Rezaannisaalsabilla12@gmail.com }}^{3}$
}

\begin{abstract}
Abstrak
Penelitian ini bertujuan untuk menentukan pengukuran kecepatan simulasi kereta api berbasis microkontroler (arduino Uno) dengan menggunakan bilangan kompleks. Pada penelitian ini dilakukan di laboratorium fisika lanjut Fakultas Keguruan dan Ilmu Pendidikan (FKIP) UHAMKA. Untuk menentukan kecepatan pada jarak tempuh yang sama menggunakan analisis fisika dan analisis matematis dengan menggunakan penerapan perhitungan bilangan kompleks $a+i b$ dengan fungsi $t, z=x+i y=\frac{i+2 t}{t-i}$. Pengambilan data menggunakan Arduino Uno R3 dan sensor inframerah. Pelaksanaan penelitian ini dilakukan dengan menggunakan jarak yang sama dan dengan variasi daya yang berbeda, sehingga diperoleh hasil penelitian. Penelitian ini dilakukan secara berulang dengan jarak yang sama namun dengan variasi daya yang berbeda. Adapun data waktu yang diperoleh dapat ditentukan pembuktian kecepatan berdasarkan analisis matematis dengan menggunakan fungsi bilangan kompleks. Pada penelitian ini dapat dibuktikan besarnya kecepatan pada jarak yang sama adalah konstan baik menggunakan analisis fisika maupun matematis. Hal ini membuktikan berlakunya aturan gerak lurus beraturan $(G L B)$ dari percobaan yang berulang dengan jarak tempuh yang sama sehingga diperoleh kecepatan yang konstan dari setiap percobaan, adapun penentuan percepatan pada percobaan ini yaitu percepatan sama dengan nol ( $a=0)$
\end{abstract}

Kata kunci: Microcontroler (Arduino Uno R3), bilangan kompleks, sensor inframerah, GLB

\section{PENDAHULUAN}

Mikrokontroler merupakan sebuah chip atau IC yang berfungsi sebagai pengontrol rangkaian elektronika. Di dalam mikrokontroler terdapat prosesor dan flash memori yang bisa dibaca atau ditulis sampai dengan 1000 kali, sehingga biaya pengembangannya menjadi lebih murah karena program dapat dihapus dan diisi kembali dengan program lainnya sesuai dengan kebutuhan.

Mikrokontroler umumnya terdiri dari CPU (Central Processing Unit), memori Input atau Output dan unit pelengkap lainnya seperti ADC (Analog To Digital Concerter) yang sudah terintegrasi di dalamnya sehingga menjadi satu kesatuan kontrol sistem.

Pemanfaatan mikrokontroler sangat perlu untuk alat-alat percobaan yang membutuhkan ketelitian dan keakurasian pengukuran yang tinggi. Salah satunya percobaan simulasi kecepatan kerata api untuk menetapkan waktu dan jarak[2]. Alat yang dimodifikasi tersebut masih menggunakan komputer sebagai pengendali alat dan penampil data. Selanjutnya alat tersebut dikembangkan terus dengan menggunakan mikrokontroler yang menggantikan posisi komputer[1]. Penggunaan mikrokontroler selain praktis, komponen ini ringan dan tidak menggunakan tempat yang luas. Dengan demikian alat menjadi mudah dipindahkan dan dioprasikan di mana saja[1].

Hal ini sangat menguntungkan jika menggunakan mikrokontroler Arduino Uno R3 dan sensor inframerah untuk menghitung suatu ketelitian dalam fisika matematika, salah satunya dalam perhitungan bilangan kompleks. Bilangan kompleks adalah salah satu metode pada analisis numerik dalam penyelesaian persamaan diferensial. Metode bilangan kompleks merupakan salah satu cara analitis untuk menyatakan vektor posisi, kecepatan dan percepatan dalam bentuk bilangan kompleks[7.8]. Langkah pertama yang perlu dilakukan adalah menentukan vektor posisi dari titik-titik yang akan dianalisis, kemudian 
menentukan vektor kecepatan dan percepatan dengan cara diferensiasi terhadap waktu. Setelah itu dilakukan, maka dapat dibuat algoritma dan kemudian persamaan matematika yang dihasilkan dimasukan kedalam program komputer dan di upload kedalam mikrokontroler Arduino Uno R3[3].

\section{LANDASAN TEORI \\ a. Mikrokontroler}

Mikrokontroler adalah sistem mikroprosesor yang terdapat didalam sebuah chip. Didalam sebuah mikrokontroler sudah terdapat komponen mikroprosesor, yakni memori dan antarmuka $\mathrm{I} / \mathrm{O}$, ada beberapa jenis mikrokontroler yang sudah memiliki fasilitas ADC, PLL, EEPROM dalam satu sistem. Arduino adalah plathform komputasi fisik yang bersifat open source berbasis rangkaian input atau output sederhana, yang dapat digunakan untuk mengembangkan objek interaktif secara mandiri dan memudahkan penggunaan elektronika diberbagai bidang. [4]

Penelitian ini digunakan jenis Arduino Uno R3. Arduino Uno adalah sebuah papan pengembangan mikrokontroler yang didasarkan pada chip ATmega328. Pada Gambar 1. Arduino Uno R3 berfungsi untuk mengendalikan sebuah sistem kerja dari sensor inframerah yang dirancang dan diproses akuisisi dalam data secara serial.

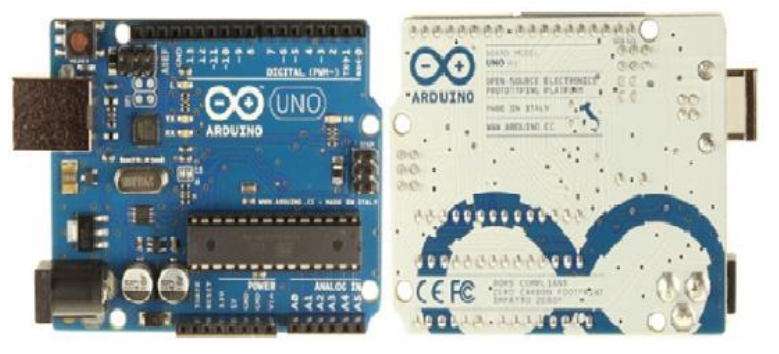

Gambar 1 Papan Arduino Uno R3

\section{b. Sensor inframerah}

Sensor infaramerah adalah sebuah komponen elektronika yang dapat mendeteksi sebuah benda ketika cahaya inframerah tertutup oleh sebuah benda. Sensor inframerah terdiri dari pemancar (infrared) dan penerima cahaya inframerah (foto transistor). Fungsi sensor inframerah untuk menentukan waktu tempuh dari kereta api pada jarak yang sama sehingga dapat mengetahui kecepatan kereta api menggunakan analisis fisika dan analisis matematis menggunakan penerapan perhitungan bilangan kompleks.

Percobaan ini dilakukan menggunakan Mikrokontroler Arduino Uno R3 sebagai pengendali yang diintegrasikan dengan dua buah sensor inframerah yang dipasang secara sejajar, sensor inframerah digunakan sebagai switch sekaligus mengaktifkan perhitungan waktu (stopwatch) saat dilewati sebuah benda sehingga dapat menghitung waktu yang dibutuhkan untuk melewati posisi pada sensor. Dalam pengambilan data, sensor telah terintegrasi dengan program pada Arduino Uno R3 untuk mengatur fungsi utama dari percobaan sebagai penghitung waktu (stopwatch). Dari kedua kali pengambilan data pengujian untuk penentukan nilai kecepatan kereta api yang dilakukan pada jarak antara sensor inframerah pertama dan sensor inframerah kedua dengan jarak satu meter $(1 \mathrm{~m})$.

\section{c. Bilangan Kompleks}

Bilangan kompleks dalam matematika, adalah sebuah bilangan yang mempunyai bentuk a + bi, di mana $a$ dan $b$ adalah bilangan riil, $i$ adalah suatu bilangan imajiner di mana $i^{2}=$ -1 . Jika pada suatu bilangan kompleks nilai $b=$ 0 , maka bilangan kompleks tersebut menjadi sama dengan bilangan real $a$.

Bilangan kompleks sama seperti bilangan rill dapat ditambah, dikurang, dikali, dan dibagi. Akan tetapi bilangan kompleks mempunyai sifatsifat tambahan yang menarik. Misalnya, setiap persamaan aljabar polinomial mempunyai solusi bilangan kompleks, tidak seperti bilangan riil yang hanya memiliki sebagian[6].

a). Notasi dan operasi

Himpunan bilangan kompleks dapat dinotasikan dengan C atau C. Bilangan real (R), dapat dinyatakan sebagai bagian dari himpunan $\mathrm{C}$ dengan menyatakan setiap bilangan real sebagai bilangan kompleks. Bilangan kompleks dapat ditambah, dikurang, dan dikali dengan menggunakan sifat-sifat aljabar seperti asosiatif, komutatif, dan distributif, dan dengan persamaan $i^{2}=-1$ :

$$
\begin{aligned}
(a+b i)+(c+d i) & =(a+c)+(b+d) i \\
(a+b i)-(c+d i) & =(a-c)+(b-d) i \\
(a+b i)(c+d i) & =a c+b c i+a d i+b d i^{2} \\
& =(a c-b d)+(b c+a d) I
\end{aligned}
$$

Secara formal bilangan kompleks dapat didefinisikan sebagai bilangan real $(a, b)$ dengan operasi sebagai berikut:

$$
(a, b)+(c, d)=(a+c, b+d)
$$




$$
(a, b) .(c, d)=(a c-b d),(b c+a d)
$$

dari definisi di atas, bilangan kompleks akan membentuk suatu himpunan yang dinotasikan dengan $\mathbf{C}$.

Bilangan kompleks dalam operasi-operasi aljabar

$$
\begin{aligned}
& \text { a. Penjumlahan } \\
& z_{1}+z_{2}=\left(x_{1}+x_{2}\right)+i\left(y_{1}+y_{2}\right) \\
& \text { b. Pengurangan } \\
& z_{1}-z_{2}=\left(x_{1}-x_{2}\right)+i\left(y_{1}-y_{2}\right) \\
& \text { c. Perkalian } \\
& z_{1} \times z_{2}=\left(x_{1}+i y_{1}\right) \times\left(x_{2}+i y_{2}\right) \\
& \text { d. Pembagiaan } \\
& \frac{z_{1}}{z_{1}}=\frac{z_{1}}{z_{2}} \frac{z_{2}^{*}}{z_{2}^{*}} \\
& =\frac{\left(x_{1}+i y_{1}\right)}{\left(x_{2}+i y_{2}\right)} \frac{\left(x_{2}-i y_{2}\right)}{\left(x_{2}-i y_{2}\right)}
\end{aligned}
$$

b). Bentuk penyajian bilangan kompleks

$$
\begin{aligned}
& \text { a. Bentuk Polar } \\
& \begin{aligned}
z & =r[\cos \theta+i \sin \theta] \\
& =r \cos \theta
\end{aligned}
\end{aligned}
$$

$r=|z|$ - modulus bilangan kompleks

$\theta=\arg (z)-\operatorname{argumen}$ bilangan kompleks

Range utama argumen : $0 \leq \arg (z)+k .2 \pi$

Sehingga $: \arg (z)=\arg (z)+k \cdot 2 \pi$

Hubungan dengan bentuk rectangular di bidang di bidang argand

$r=\sqrt{x^{2}+y^{2}}$

$\theta=\tan ^{-1}\left(\frac{y}{x}\right) \cdot[6]$

\section{b. Bentuk Eksponen}

Bentuk eksponen, yaitu:

$$
r e^{i \theta}=r(\cos \theta+i \sin \theta)
$$

Kecepatan adalah besaran vektor untuk mengetahui seberapa cepat perpindahan sebuah benda, dan bisa disebut dengan kecepatan dan dapat dinyatakan dalam satuan meter per sekon $(\mathrm{m} / \mathrm{s}) .[5]$

Didefinisikan secara matematis Kecepatan biasa digunakan untuk merujuk pada kecepatan sesaat sebagai:

$$
v=\lim _{\Delta t \rightarrow 0} \frac{r(t+\Delta t)-r(t)}{\Delta t}=\frac{d r}{d t}
$$

$v$ adalah kecepatan awal dan $r(t)$ adalah perpindahan fungsi waktu. Selain kecepatan awal, dikenal juga besaran kecepatan rata-rata $v$ yang didefinisikan dalam rentang waktu $\Delta t$ yang tidak mendekati nol.

$$
v=\frac{\Delta r}{\Delta t}
$$

\section{METODOLOGI PENELITIAN}

Metodologi penelitian yang kami lakukan yaitu dengan melakukan membuktikan berlakunya aturan gerak lurus beraturan (GLB) dari percobaan yang berulang dengan jarak tempuh yang sama sehingga diperoleh kecepatan yang konstan dari setiap percobaan, adapun penentuan percepatan pada percobaan ini yaitu percepatan sama dengan nol $(a=0)$. Penelitian pembuktian penerapan fungsi bilangan kompleks yang dapat menentukan kecepatan, hal ini dapat dilihat dengan adanya persamaan pengaruh waktu terhadap kecepatan yang mempengaruhi nilai kecepatan baik dengan analisis fisika maupun analisis matematis dengan fungsi bilangan kompleks.

Pada penelitian ini dilakukan untuk menentukan kecepatan pada jarak tempuh (1m) menggunakan analisis fisika dan dengan analisis matematis menggunakan penerapan perhitungan bilangan kompleks $\mathrm{a}+\mathrm{ib}$ dengan fungsi $t, z=$ $x+i y=\frac{i+2 t}{t-i}$. Pada pelaksanaan penelitian ini dilakukan dengan menggunakan jarak yang sama dan dengan variasi daya yang berbeda. Percobaan dilakukan secara berulang dengan jarak yang sama namun dilakukan dengan variasi daya yang berbeda.

Dalam proses pengambilan data menggunakan mikrokontroler Arduino Uno R3 sebagai pengendali yang diintegrasikan dengan dua buah sensor inframerah yang dipasang secara sejajar, sensor inframerah digunakan sebagai switch sekaligus mengaktifkan perhitungan waktu (stopwatch) saat dilewati sebuah benda sehingga dapat menghitung waktu yang dibutuhkan untuk melewati posisi pada sensor. Dalam pengambilan data, sensor telah terintegrasi dengan program pada Arduino Uno R3 untuk mengatur fungsi utama dari percobaan sebagai penghitung waktu (stopwatch). Dari kedua kali pengambilan data pengujian untuk penentukan nilai kecepatan kereta api yang dilakukan pada jarak antara sensor inframerah pertama dan sensor inframerah kedua dengan jarak satu meter $(1 \mathrm{~m})$.

\section{HASIL DAN PEMBAHASAN}

Pada pelaksanaan penelitian ini dilakukan dengan menggunakan jarak yang sama dan dengan variasi daya yang berbeda. Percobaan dilakukan secara berulang dengan jarak yang sama namun dilakukan dengan variasi daya yang 
berbeda. Adapun data waktu yang diperoleh dari pembacaan sensor inframerah juga dapat ditentukan pembuktian kecepatan berdasarkan analisis matematis menggunakan fungsi bilangan kompleks. Berdasarkan percobaan daya yang pertama dengan jarak yang sama $(1 \mathrm{~m})$ diperoleh data sebagai berikut:

Tabel 1

Perolehan Data penelitian ke 1

\begin{tabular}{|c|c|c|c|c|c|c|}
\hline Daya & Percobaan & $\begin{array}{c}\text { Waktu } \\
\text { awal(s) }\end{array}$ & $\begin{array}{c}\text { Waktu } \\
\operatorname{akhir}(s)\end{array}$ & $\begin{array}{c}\text { Total } \\
\text { waktu }(s)\end{array}$ & $\begin{array}{c}\text { Kecepatan } \\
(\mathrm{m} / \mathrm{s})\end{array}$ & $\begin{array}{c}\text { Bil. } \\
\text { Kompleks } \\
(\mathrm{m} / \mathrm{s})\end{array}$ \\
\hline \multirow{3}{*}{1} & 1 & 26,331 & 37,629 & 11,298 & 0,09 & 0,02 \\
\hline & 2 & 47,698 & 58,814 & 11,116 & 0,09 & 0,02 \\
\hline & 3 & 118,889 & 129,979 & 11,090 & 0,09 & 0,02 \\
\hline \multicolumn{5}{|c|}{ Rata-rata } & 0,09 & 0,02 \\
\hline
\end{tabular}

Berdasarkan tabel 1 dari percobaan kecepetan (v1) terhadap waktu berpengaruh terhadap perhitungan bilangan kompleks. Dimana dalam kecepatan yang sama dan waktu yang berbeda akan mempengaruhi bilangan kompleks. Dalam penelitian ini kecepetan terhadap bilangan kompleks berbanding terbalik. Dimana pada percobaan pertama dengan kecepatan $0,09 \mathrm{~m} / \mathrm{s}$ dan waktu 11,298 sekon akan menghasilkan bilangan kompleks $0,02 \mathrm{~m} / \mathrm{s}$. Sedangkan percobaan kedua dengan kecepatan $0,09 \mathrm{~m} / \mathrm{s}$ dengan waktu 11,116 sekon akan menghasilkan bilangan kompleks $0.02 \mathrm{~m} / \mathrm{s}$. Kemudian dengan percobaan ketiga untuk waktu 11,090 sekon dengan kecepatan $0,09 \mathrm{~m} / \mathrm{s}$ akan menghasilkan bilangan kompleks $0,02 \mathrm{~m} / \mathrm{s}$.

Berikut adalah grafik yang menjelaskan hubungan antara kecepatan (v) terhadap waktu (t) pada masing-masing waktu 11,298 sekon, 11,116 sekon dan 11,090 sekon pada hasil perhitungan kecepatan dan bilangan kompleks.

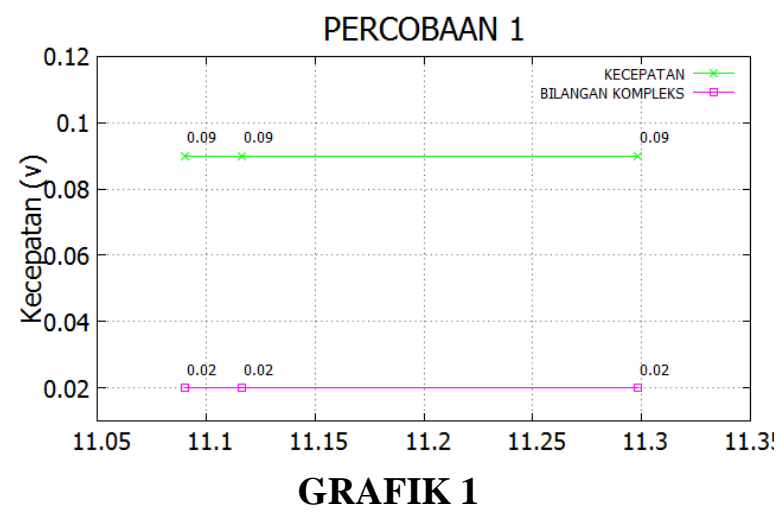

(a) Kecepatan terhadap waktu dengan menggunakan analisis fisika dan analisis matematis fungsi bilangan kompleks pada percobaan dengan menggunakan daya pertama

\section{Tabel 2}

Perolehan Data penelitian ke 2

\begin{tabular}{|c|c|c|c|c|c|c|}
\hline Daya & Percobaan & $\begin{array}{c}\text { Waktu } \\
\text { awal(s) }\end{array}$ & $\begin{array}{c}\text { Waktu } \\
\text { akhir(s) }\end{array}$ & $\begin{array}{c}\text { Total } \\
\text { waktu }(s)\end{array}$ & $\begin{array}{c}\text { Kecepatan } \\
(\mathrm{m} / \mathrm{s})\end{array}$ & $\begin{array}{c}\text { Bil. } \\
\text { Kompleks } \\
(\mathrm{m} / \mathrm{s})\end{array}$ \\
\hline \multirow{3}{*}{2} & 1 & 6,561 & 12,015 & 5,454 & 0,18 & 0,10 \\
\hline & 2 & 19,556 & 25,004 & 5,448 & 0,18 & 0,10 \\
\hline & 3 & 40,102 & 45,494 & 5,392 & 0,19 & 0,10 \\
\hline \multicolumn{5}{|c|}{ Rata-rata } & 0,18 & 0,10 \\
\hline
\end{tabular}

Kecepetan didefinisikan sebagai kemampuan bergerak secara berturut-turut untuk menempuh suatu jarak dalam satu selang waktu tertentu. Pada jarak tempuh yang sama, semakin singkat waktu yang tempuh, maka kecepatan yang di hasilkan akan semakin baik. Berdasarkan tabel perolehan data dari percobaan kecepetan (v2) terhadap waktu berpengaruh terhadap perhitungan bilangan kompleks. Dimana dalam kecepatan yang sama dan waktu yang berbeda akan mempengaruhi bilangan kompleks. Dalam penelitian ini kecepetan terhadap bilangan kompleks berbanding terbalik. Dimana pada kecepatan $0,18 \mathrm{~m} / \mathrm{s}$ dan waktu 5,454 sekon akan menghasilkan bilangan kompleks $0,10 \mathrm{~m} / \mathrm{s}$. Sedangkan kecepatan $0,18 \mathrm{~m} / \mathrm{s}$ dengan waktu 5,448 sekon akan menghasilkan bilangan kompleks $0.10 \mathrm{~m} / \mathrm{s}$. Kemudian untuk waktu 5,392 sekon dengan kecepatan $0,19 \mathrm{~m} / \mathrm{s}$ akan menghasilkan bilangan kompleks $0,10 \mathrm{~m} / \mathrm{s}$.

Berikut adalah grafik yang menjelaskan hubungan antara kecepatan (v) terhadap waktu (t) pada masing-masing waktu 5,454 sekon, 5,448 sekon dan 5,392 sekon pada hasil perhitungan kecepatan dan bilangan kompleks.

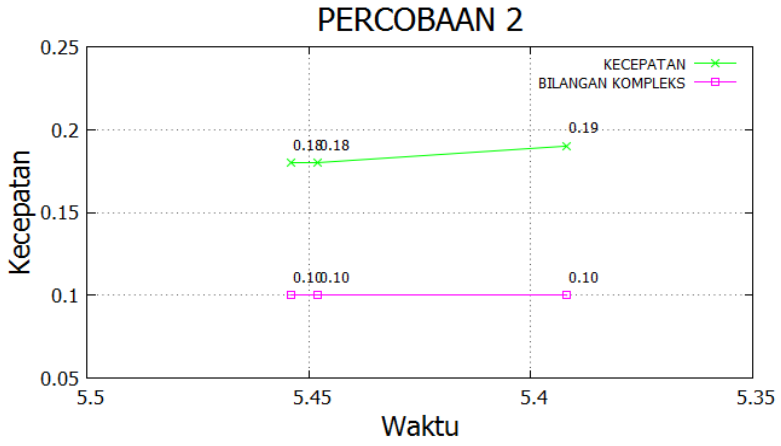

GRAFIK 2

(b) Kecepatan terhadap waktu dengan menggunakan analisis fisika dan analisis matematis fungsi bilangan kompleks pada percobaan dengan menggunakan daya kedua

Berdasarkan grafik 1 dan grafik 2 dapat dilihat bahwa pada percobaan ini dapat dibuktikan dengan berlakunya aturan gerak lurus beraturan (GLB) dari percobaan yang berulang dengan jarak tempuh yang sama sehingga 
diperoleh kecepatan yang konstan dari setiap percobaan, adapun penentuan percepatan pada percobaan ini yaitu percepatan sama dengan nol $(\mathrm{a}=0)$

Adapun berdasarkan perbandingan data dari kedua percobaan dapat dilihat hubungan kecepatan $(v)$ terhadap waktu $(t)$ disetiap percobaan. Hubungan kecepatan $(v)$ terhadap waktu $(t)$ dari kedua percobaan dengan jarak yang berbeda ditunjukan pada grafik berikut 3 .

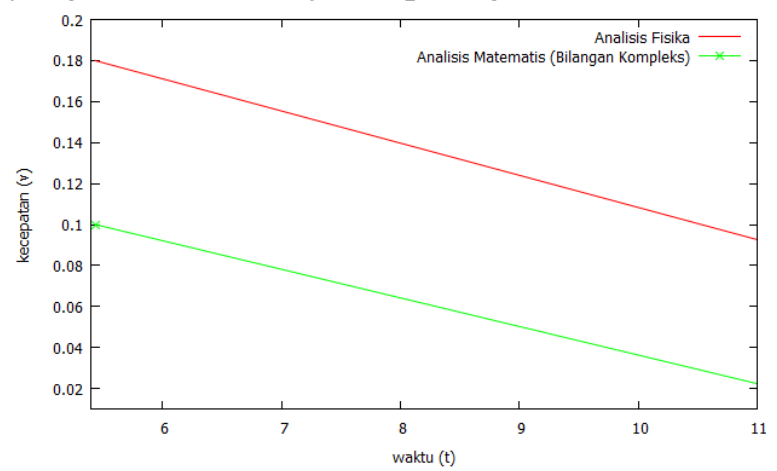

Grafik 3

Grafik hubungan waktu terhadap kecepatan dengan menggunakan daya yang berbeda berdasarkan analisis fisika (merah) dan analisis matematis dengan menggunakan bilangan kompleks (hijau)

Berdasarkan grafik tersebut, dapat disimpulkan hubungan besarnya kecepatan pada masing-masing waktu berpengaruh terhadap bilangan kompleks. Semakin besar waktu maka kecepatan semakin kecil sebaliknya semakin kecil waktu maka kecepatan semakin besar. Hal ini berlaku sebagaimana hubungan secara analisis fisika yaitu $v=\frac{s}{t}$, dimana $v$ berbanding terbalik pada $t$. Hal ini yang juga dapat dirasakan gejalanya ketika pelaksanaan penelitian dengan arus v2 waktu yang dibutuhkan untuk menghasilkan nilai bilangan kompleks lebih cepat dibanding dengan $v 1$.

\section{SIMPULAN}

Berdasarkan hasil penelitian maka dapat disimpulkan penggunaan mikrokontroler Arduino Uno R3 dan sensor inframerah dapat digunakan sebagai switch sekaligus mengaktifkan perhitungan waktu (stopwatch) saat dilewati sebuah benda, sehingga dapat menghitung waktu secara akurat dalam menentukan kecepatan kereta api menggunakan fungsi bilangan kompleks. Hal ini dapat dilihat dengan adanya persamaan pengaruh waktu terhadap kecepatan yang mempengaruhi nilai kecepatan baik dengan analisis fisika maupun analisis matematis dengan fungsi bilangan kompleks, semakin besar waktu maka semakin kecil pula bilangan kompleks. Untuk jarak yang sama dengan daya yang sama diperoleh pembuktian gerak lurus beraturan (GLB) dimana kecepatannya konstan. Adapun perubahan variasi daya mempengaruhi besarnya waktu yang mempengaruhi kecepatan, dimana waktu berbanding terbaik terhadap kecepatan. Semakin besar waktu maka kecepatan semakin kecil sebaliknya semakin kecil waktu maka kecepatan semakin besar. Hal ini berlaku sebagaimana hubungan secara analisis fisika yaitu, dimana $v$ berbanding terbalik pada $t$. Gejala ini dapat dirasakan ketika pelaksanaan penelitian kecepatan v2 lebih cepat mengalami kenaikan bilangan kompleks dibandingkan dengan kecepatan $\mathrm{v} 1$.

\section{KEPUSTAKAAN}

[1] Elisa, dkk. 2018. speed measurement and acceleration of arduino-based microcontroller on objects roll in the incline plane. journal of science and technology. vol 7 (2) : $166-175$

[2] Sumah, A., 1994, Penuntun Praktikum Fisika Dasar I, Laboratorium Fisika Dasar Fakultas MIPA, Teknik, Pertanian dan Kedokteran Umum, Universitas Hasanuddin.

[3] Novri. 2014. Analisis Kecepatan dan Percepatan Gerak Robot Joules Menggunakan Metode Bilangan Kompleks Jurnal Mechanical, Volume 5, Nomor 2

[4] Steven Jendri Sokop, dkk. 2016. Trainer Periferal Antarmuka Berbasis Mikrokontroler Arduino Uno. Teknik Elektro dan Komputer vol.5 no.3 (2016), ISSN : 2301-8402

[5] Alatas, Husin. 2014. Buku Pelengkap Fisika Matematika. Bogor: Departement Fisika

[6] Ermawaty, Imas Ratna. 2016. Fisika Matematika, Jakarta: UHAMKA PRESS.

[7] Kimbrell, J.T., 1991, Kinematics analysis and synthesis, McGraw-Hill Book Co. Singapore.

[8] Purbosari, Riris dan Imas Ratna Ermawaty, Menganalisis Fungsi Implisit Pada Kecepatan Dan Percepatan Mobil-Mobilan Pada Massa Yang Berbeda. Prosiding Seminar Nasional Fisika (E-Jurnal) SNF2015 Vol.5, e-ISSN: 2476-9398 